\title{
Biochemical and immunological characterization of haemolysin produced by Pseudomonas aeruginosa PAO1 isolated from burn wounds
}

\author{
${ }^{* 1}$ Allam, A. A., ${ }^{2}$ El-shawadfy, A. M., ${ }^{2}$ Hassanein W. A. E., ${ }^{2}$ Hamza, E. H. A., ${ }^{1}$ Morad, E. A., \\ ${ }^{1}$ El Shafei, M. A. E., and ${ }^{3}$ El Etriby, D. E.
${ }^{1}$ Medical Microbiology and Immunology Department, Faculty of Medicine, Zagazig University, Egypt ${ }^{2}$ Botany and Microbiology Department, Faculty of Science, Zagazig University, Egypt ${ }^{3}$ Infection Control Unit, Specialized Internal Medicine Hospital, Mansoura University, Egypt *Correspondence to: Egyayman66@yahoo.com; 0020155777174; 00201227989609

\begin{abstract}
:
Background: Infection of burn wounds by multidrug-resistant (MDR) Pseudomonas aeruginosa ( $P$. aeruginosa) is a leading cause of morbidity and mortality and remains one of the most challenging concerns for the burns unit. The aim of this study is purify and characterize the haemolysin produced by multidrug resistant $P$. aeruginosa PAO1 isolated from burn wounds.

Methods: Isolation and identification of $P$. aeruginosa from burns was done by standard bacteriological methods. $P$. aeruginosa PAO1 was identified by PCR amplification and sequencing of the 16S rRNA gene. The haemolysin of $P$. aeruginosa PAO1 was purified by $70 \%$ ammonium sulphate precipitation followed by gel filtration on Sephadex G-100, and separation by SDS-Poly Acrylamide Gel Electrophoresis. In vivo toxicity of the purified haemolysin was determined by intraperitoneal injection of Swiss albino mice, and in vitro toxinantitoxin neutralization test was performed as previously described.

Results: The pure haemolysin had a molecular weight of $37 \mathrm{kDa}$, with maximum activity at $25^{\circ} \mathrm{C}$ for 30 minutes and stable within $\mathrm{pH}$ range of 4-9 (maximum activity at $\mathrm{pH} 7$ ). The haemolysin was activated by $\mathrm{Ca}^{2+}$, $\mathrm{Fe}^{3+}$ and $\mathrm{Cu}^{2+}$. Intraperitoneal injection of mice with $0.5 \mathrm{ml}$ of haemolysin $(128 \mathrm{HU} / \mathrm{ml})$ caused $100 \%$ mortality while 0.5 and $0.1 \mathrm{ml}$ of haemolytic titer $(64 \mathrm{HU} / \mathrm{ml}$ ) of the heated haemolysin (toxoid) caused $50 \%$ and $0 \%$ mortality respectively. In vitro toxin-antitoxin neutralization test revealed that anti-haemolysin antitoxin was present in the serum of the mice that were previously vaccinated with heated toxin.

Conclusion: This study concluded that haemolysin can be a potential vaccine component for prevention of haemolysis caused by multidrug resistant $P$. aeruginosa in burn patients.
\end{abstract}

Keywords: haemolysin, Pseudomonas aeruginosa, multidrug resistant organism

Received August 31, 2019; Revised November 30, 2019; Accepted January 6, 2020

Copyright 2020 AJCEM Open Access. This article is licensed and distributed under the terms of the Creative Commons Attrition 4.0. International License (http://creativecommmons.org/licenses/by/4.0), which permits unrestricted use, distribution and reproduction in any medium, provided credit is given to the original author(s) and the source.

\section{Caractérisation biochimique et immunologique de I'hémolysine produite par Pseudomonas aeruginosa PAO1 isolée de brûlures}

\author{
${ }^{* 1}$ Allam, A. A., ${ }^{2}$ El-shawadfy, A. M., ${ }^{2}$ Hassanein W. A. E., ${ }^{2}$ Hamza, E. H. A., ${ }^{1}$ Morad, E. A, \\ ${ }^{1}$ El Shafei, M. A. E., et ${ }^{3}$ El Etriby, D. E. \\ ${ }^{1}$ Département de microbiologie médicale et d'immunologie, Faculté de médecine, Université de Zagazig, Égypte \\ ${ }^{2}$ Département de botanique et de microbiologie, Faculté des sciences, Université de Zagazig, Egypte \\ ${ }^{3}$ Unité de contrôle des infections, Hôpital spécialisé en médecine interne, Université Mansoura, Egypte \\ *Correspondance à: Egyayman66@yahoo.com; 0020155777174; 00201227989609
}

\begin{abstract}
Abstrait:
Contexte: L'infection des plaies par brûlures par Pseudomonas aeruginosa ( $P$. aeruginosa) multirésistante (MDR) est l'une des principales causes de morbidité et de mortalité et demeure l'une des préoccupations les
\end{abstract}


plus difficiles pour l'unité des brûlures. Le but de cette étude est de purifier et de caractériser l'hémolysine produite par $P$. aeruginosa PAO1 multirésistante isolée de brûlures.

Méthodes: L'isolement et l'identification de $P$. aeruginosa des brûlures ont été effectués par des méthodes bactériologiques standard. $P$. aeruginosa PAO1 a été identifié par amplification par PCR et séquençage du gène d'ARNr 16S. L'hémolysine de $P$. aeruginosa PAO1 a été purifiée par une précipitation au sulfate d'ammonium à $70 \%$ suivie d'une filtration sur gel sur Sephadex G-100 et d'une séparation sur électrophorèse par gel SDS-Poly Acrylamide. La toxicité in vivo de l'hémolysine purifiée a été déterminée par injection intrapéritonéale de souris albinos suisses et un test de neutralisation in vitro toxine-antitoxine a été effectué comme décrit précédemment.

Résultats: L'hémolysine pure avait un poids moléculaire de $37 \mathrm{kDa}$, avec une activité maximale à $25^{\circ} \mathrm{C}$ pendant 30 minutes et stable dans une plage de $\mathrm{pH}$ de 4 à 9 (activité maximale à $\mathrm{pH} 7$ ). L'hémolysine a été activée par $\mathrm{Ca}^{2+}, \mathrm{Fe}^{3+}$ et $\mathrm{Cu}^{2+}$. L'injection intrapéritonéale de souris avec 0,5 ml d'hémolysine (128 HU/ml) a causé une mortalité de $100 \%$ tandis que 0,5 et $0,1 \mathrm{ml}$ de titre hémolytique (64 HU/ml) de l'hémolysine chauffée (anatoxine) ont causé respectivement $50 \%$ et $0 \%$ de mortalité. Un test de neutralisation in vitro toxine-antitoxine a révélé que l'antitoxine anti-hémolysine était présente dans le sérum des souris préalablement vaccinées avec de la toxine chauffée.

Conclusion: Cette étude a conclu que l'hémolysine peut être un composant vaccinal potentiel pour la prévention de l'hémolyse causée par $P$. aeruginosa multirésistante chez les patients brûlés.

Mots-clés: hémolysine, Pseudomonas aeruginosa, organisme multirésistant

\section{Introduction:}

Infection in burn patients is a leading cause of morbidity and mortality and remains one of the most challenging concerns for the burns unit (1). Multidrug-resistant (MDR) Pseudomonas aeruginosa ( $P$. aeruginosa) is an emerging cause of mortality and morbidity in burn patients, which is estimated to cause $4-60 \%$ of nosocomial infections in different parts of the world (2).

Numerous $P$. aeruginosa virulence factors contribute to the pathogenesis of wound infections in patients with burns. Pili and flagella are essential for the organism ability to persist in burns wound and cause disseminated infections (3). $P$. aeruginosa elaborate many toxic products and enzymes such as catalase, lipase, lecithinase, elastase, proteases and haemolysins, which enable the organism to invade and destroy the host tissues (4-6). In particular, haemolysin contributes to virulence of $P$. aeruginosa, and decreased haemolytic activity has been associated with decrease virulence (7).

The aim of current study is to purify and characterize the haemolysin produced by MDR $P$. aeruginosa PAO1 isolated from burn patients as a preliminary step to producing toxoid from it.

\section{Materials and method:}

\section{Study setting}

This study was conducted in the Medical Microbiology and Immunology Department, Faculty of Medicine, and Botany Department Faculty of Science, Zagazig University, Egypt. Approval for performing the study was obtained from Institutional Review Board of Faculty of Medicine, Zagazig University. Consent was obtained from each patient enrolled in the study. All experiments were carried out in compliance with the relevant laws and guidelines.

\section{Collection of specimens}

Forty five swab specimens were collected using sterile cotton swabs from patients with burn wound infections in Central Hehia Hospital, Hehia city, El-Sharkia, Egypt during the period July to September 2013. All samples were transported to the Medical Microbiology and Immunology Department, Faculty of Medicine, Zagazig University, within two hours of collection.

\section{Isolation and identification of Pseudomonas aeruginosa}

The swabs were cultured on nutrient, MacConkey and blood agar plates, and incubated aerobically at $37^{\circ} \mathrm{C}$ for 24 hours. Colonies were identified as $P$. aeruginosa on culture plates using standard bacteriological methods (8). Antibiotic susceptibility of $P$. aeruginosa isolates was determined by the CLSI disk diffusion method (9). The identity of the MDR $P$. aeruginosa was confirmed by PCR amplification and sequencing of the $16 \mathrm{~S}$ rRNA gene at the Sequence Unit, Sigma Company, Giza, Egypt as $P$. aeruginosa PAO1 (NR 074828 1).

\section{Determination of haemolysin level}

The haemolysin level of $P$. aeruginosa PAO1 (NR 0748281 ) was determined by the modified disk diffusion method (10). The overnight broth culture of the isolates was diluted in sterile saline to 0.5 McFarland standards. Sterile filter paper disk was immersed in each bacterial suspension to absorb $0.01 \mathrm{ml}$. The disks were placed on the surface of blood agar medium and incubated overnight at $37^{\circ} \mathrm{C}$. Diameters of haemolysis $(\mathrm{H})$ and growth $(G)$ zones were measured and the $H / G$ ratio was determined.

\section{Haemolysin purification}

P. aeruginosa PAO1 (NR 074828 1) was grown in nutrient broth medium at optimum conditions for maximum haemolysin produc- 
tion. The medium was optimized in presence of glucose as carbon source and yeast extract as nitrogen source at $\mathrm{pH} 7.0$ for 2 days. The culture supernatant was mixed with $70 \%$ ammonium sulphate concentration, with constant stirring at $4^{\circ} \mathrm{C}$ overnight. The precipitate was then separated by centrifugation at $4000 \mathrm{rpm}$ for 20 minutes and resuspended in small amount of phosphate buffer $(\mathrm{pH}$ 7.0). The re-suspended pellets were applied to a Sephdex G-100 column pre-equilibrated with the same buffer. The active fractions were collected, pooled and concentrated by dialysis against the same buffer. For each fraction, protein content and haemolytic activity were determined by methods previously described $(11,12)$.

\section{Haemolytic titer}

The titer of $P$. aeruginosa PAO1 haemolysin was determined using two fold dilution method (13). $0.5 \mathrm{ml}$ of haemolysin of was diluted by two fold serial dilutions in $0.5 \mathrm{ml}$ phosphate buffered saline $(\mathrm{pH} 7.4)$. $0.5 \mathrm{ml}$ of $1 \%$ suspension of red cells was added to tubes containing the dilutions of the haemolysin. The final readings were made visually after 2 hours of incubation at $37^{\circ} \mathrm{C}$ in a water bath. The reciprocal of the highest dilution showing complete haemolysis was taken as the number of haemolytic units per $\mathrm{ml}(\mathrm{HU} / \mathrm{ml})$ present in the preparations

\section{Determination of molecular weight}

SDS-polyacrylamide gel electrophoresis (SDS-PAGE) was carried out to determine the purity and molecular weight of the protein, as described by Laemmli (14) using $12 \%$ separating acrylamide gel.

\section{Amino acid analysis}

Amino acid composition of the purified protein was determined by applying the GLC hydrolytic technique (15) with a Beckman amino acid analyzer system (Sykam-S 7130 Amino Acids, Reagent Orgaizer).

Biochemical properties of purified haemolysin Thermal stability of the haemolysin was studied after pre-incubation at various temperature $\left(25,37,45,55\right.$ and $\left.75^{\circ} \mathrm{C}\right)$ using $0.01 \mathrm{M}$ phosphate buffer $(\mathrm{pH} 7.0)$ for different periods of time $(30,60,90$ and 120 minutes). A $1 \%$ RBCs suspension was added to the haemolysin $(0.5 \mathrm{ml} / 0.5 \mathrm{ml} \mathrm{v} / \mathrm{v})$. The thermal inactivation rate $(\mathrm{Kr} \min )$ was described by the first-order kinetic model (16); Ln $\left(A_{t} / A_{0}\right) k_{t} T$, where $A_{o}$ and $A_{t}$ are the specific activity at zero and ' $t$ ' time respectively. The $T_{1 / 2}$ (time at which the haemolysin loses $50 \%$ of its activity) was calculated from the linear equation for each temperature. The temperature at which the haemolysin loses $50 \%$ of its activity ( $\mathrm{Tm}$ ) was calculated from the linear equation of different pre-incubation temperature at 60 minutes.

The stability of the haemolysin was examined after pre-incubation for 30 minutes at different $\mathrm{pH}$ values (4, 5, 6, 7, 8 and 9). Acetate $(0.2 \mathrm{M})$, phosphate $(0.2 \mathrm{M})$ and Tris $\mathrm{HCl}(0.2 \mathrm{M})$ buffers were used to create $\mathrm{pH}$ range 4-5, 6-7 and 8-9 respectively. After adding $1 \%$ RBCs suspension and incubating at $37^{\circ} \mathrm{C}$ for 2 hours, the haemolytic activity was determined for each $\mathrm{pH}$

To assay the metal ions effect, the purified haemolysin was pre-incubated in $1 \mathrm{mM}$ EDTA at $37^{\circ} \mathrm{C}$ for 10 minutes and then dialyzed against $0.01 \mathrm{M}$ phosphate buffer $(\mathrm{pH}$ 7.0). The haemolysin was incubated with each metal ion separately for 30 minutes before adding $1 \%$ RBCs suspension. Metal ions in form of $\mathrm{FeSO} 4, \mathrm{CuSO}_{4}, \mathrm{MgSO}_{4}$, $\mathrm{ZnSO}_{4}, \mathrm{CaCO}_{3}$, Iodine $(5 \mathrm{mM})$ as well as EDTA ( 1 and $5 \mathrm{mM}$ ) were used. The haemolytic activity was determined after incubation at $37^{\circ} \mathrm{C}$ for 2 hours.

Mice toxicity of fresh and heated haemolysin The purified haemolysin was heated for 15 minutes in a boiling water bath to prepare the toxoid (17). The haemolytic titer of the fresh (toxin) and heated (toxoid) haemolysin was determined as described previously (13). Six groups of four male Swiss albino mice (6-8 weeks old) were injected intra-peritoneally with doses of 0.5 , 0.3 and $0.1 \mathrm{ml}$ of the purified toxin (groups $A$, $B$ and $C$ ) and toxoid (groups D, E and F). The toxicity reflected by the mortality rate in each group was measured using the following equation (18);

$$
\text { Mortality rate }=\frac{\text { Number of animals that died }}{\text { Total number of animals per group }}
$$

In vitro toxin-anti-toxin neutralization test Toxin neutralization test was performed to detect the presence of serum antibodies that can neutralize the haemolytic properties of the haemolysin. Blood sample was obtained from five Swiss albino mice previously immunized by repeatedly injecting them with $0.1 \mathrm{ml}$ toxoid after which their sera were separated. Fifty, $45,40,35$ and $30 \mu \mathrm{L}$ of serum from the immunized mice were added to $0,5,10,15$ and $20 \mu \mathrm{L}$ of haemolysin respectively. $25 \mu \mathrm{L}$ of $1 \%$ RBC suspension was added to each tube and incubated at $37^{\circ} \mathrm{C}$ for 6 hours. All tubes were centrifuged for 2 minutes and the supernatants were examined for haemolysis. The last tube with no haemolysis was the endpoint of the test (19), which contains the least concentration of the antibody that neutralizes the haemolysin. 


\section{Results:}

\section{Purification of haemolysin}

As shown in Table 1 , the haemolytic activity was 32, 64 and $128 \mathrm{HU} / \mathrm{ml}$ for the crude broth culture filtrate, after precipitation with $70 \%$ ammonium sulphate and following gel filtration chromatography on Sephadex G-100 respectively. Compared to the crude culture broth filtrate, the haemolysin was more purified with purification factor of 29.7 and 10.7 fold using chromatography and $70 \%$ ammonium sulphate precipitation respectively. The haemolysin was purified as an extracellular enzyme from the liquid cultures of $P$. aeruginosa PAO1 growing in broth medium ( $\mathrm{pH} 7)$. The purification profile of tested haemolysin using sephadex-G100 showed a sharp peak containing the active haemolysin in fractions 9 to 11 with specific activity $196.9 \mathrm{Umg}^{-1}$ proteins compared to 6.6 $\mathrm{Umg}^{-1}$ of the crude protein (Table 1 ).

Molecular weight of purified haemolysin Fig 1 shows the SDS-PAGE of the purified haemolysin of $P$. aeruginosa with one major band of approximately $37 \mathrm{KDa}$.

\section{Amino acids of purified haemolysin}

As shown in Table 2, the haemolysin was composed of $40.2 \%$ neutral amino acids (glycine, valine, leucine, isoleucine and alanine), 20.7\% acidic amino acids (glutamic acid and aspartic acid), $19.7 \%$ basic amino acids (lysine and arginine), and $60.9 \%$ oxy amino acids (serine, threonine and proline). The haemolysin has high concentration of glycine (26.7\%) among other detected amino acids.

Table 1: Purification of the haemolysin from Pseudomonas aeruginosa PA01 using different methods

\begin{tabular}{lccccc}
\hline Purification step & $\begin{array}{c}\text { Haemolytic } \\
\text { activity } \\
\text { (HU/ml) }\end{array}$ & $\begin{array}{c}\text { Protein } \\
(\mathrm{mg} / \mathrm{ml})\end{array}$ & $\begin{array}{c}\text { Specific } \\
\text { activity } \\
\text { (HU/mg } \\
\text { protein) }\end{array}$ & $\begin{array}{c}\text { Purification factor } \\
\text { (folds) }\end{array}$ & \% Recovery \\
\hline $\begin{array}{c}\text { Culture broth } \\
\text { (crude) }\end{array}$ & 32 & 4.83 & 6.62 & 1.0 & 100 \\
$\begin{array}{c}70 \% \text { ammonium } \\
\text { sulphate }\end{array}$ & 64 & 1.12 & 70.90 & 10.7 & 20.9 \\
$\begin{array}{c}\text { Sephadex G-100 } \\
\text { Sepros }\end{array}$ & 128 & 0.65 & 196.92 & 29.7 & 15.6 \\
\hline
\end{tabular}

$\mathrm{HU}=$ haemolytic units

Table 2: Amino acids composition of $P$. aeruginosa PAO1 haemolysin

\begin{tabular}{ccc}
\hline Amino acid name & $\begin{array}{c}\text { Concentration } \\
(\mathrm{mg} / 100 \mathrm{ml})\end{array}$ & Ratio (\%) \\
\hline Aspartic & 2.32 & 5.76 \\
Threonine & 1.21 & 3.00 \\
Serine & 1.31 & 3.25 \\
Glutamic & 6.00 & 14.92 \\
Proline & 5.42 & 13.47 \\
Glycine & 10.74 & 26.7 \\
Alanine & 1.48 & 3.68 \\
Valine & 1.30 & 3.23 \\
Isoleucine & 0.94 & 2.33 \\
Leucine & 1.72 & 4.27 \\
Histidine & 2.54 & 6.31 \\
Lysine & 2.81 & 6.98 \\
Arginine & 2.42 & 6.01 \\
\hline
\end{tabular}

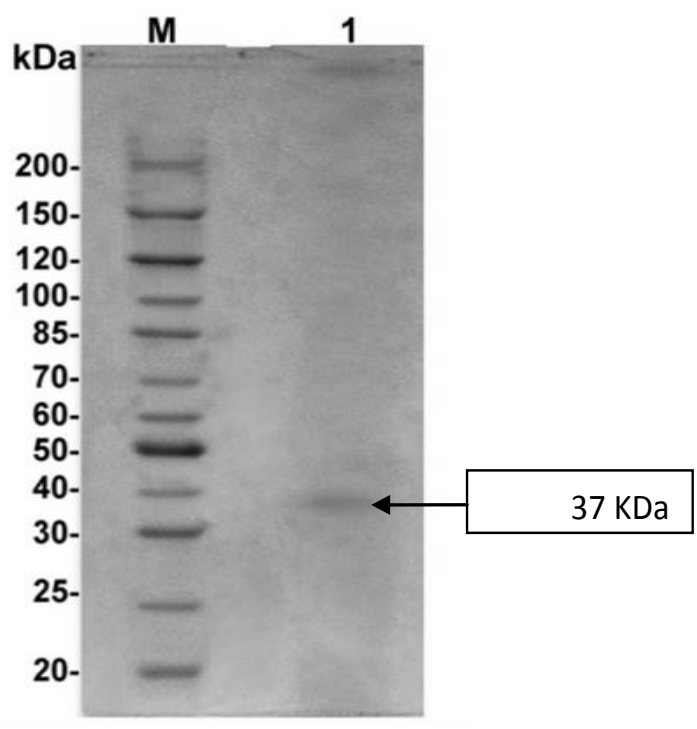

Fig.1: SDS-PAGE profile of purified haemolysin of Pseudomonas aeruginosa PAO1 shows that molecular weight of the purified enzyme was $37 \mathrm{KDa}$ (Lane 1) when compared to the protein markers (Lane M) 
Table 3: Biochemical characters of Pseudomonas aeruginosa haemolysin

\begin{tabular}{|c|c|c|c|}
\hline Temperature $\left({ }^{\circ} \mathrm{C}\right)$ & Time (minute) & $\begin{array}{c}\text { Hemolytic activity } \\
(\mathrm{HU} / \mathrm{ml})\end{array}$ & Relative activity \% \\
\hline \multirow{2}{*}{25} & 30 & 127.4 & 100 \\
\hline & $\begin{array}{c}60 \\
90 \\
120 \\
30\end{array}$ & $\begin{array}{l}120.9 \\
115.6 \\
112.8 \\
107.4\end{array}$ & $\begin{array}{l}94.8 \\
90.7 \\
88.5 \\
84.3\end{array}$ \\
\hline 37 & $\begin{array}{c}60 \\
90 \\
120 \\
30\end{array}$ & $\begin{array}{l}104.9 \\
95.4 \\
93.9 \\
87.3\end{array}$ & $\begin{array}{l}82.3 \\
74.8 \\
73.7 \\
68.5\end{array}$ \\
\hline 45 & $\begin{array}{c}60 \\
90 \\
120 \\
30\end{array}$ & $\begin{array}{l}85.8 \\
84.7 \\
83.0 \\
75.9\end{array}$ & $\begin{array}{l}67.3 \\
66.4 \\
65.1 \\
59.6\end{array}$ \\
\hline 55 & $\begin{array}{c}60 \\
90 \\
120 \\
30\end{array}$ & $\begin{array}{l}68.1 \\
64.0 \\
63.1 \\
55.3\end{array}$ & $\begin{array}{l}53.4 \\
50.2 \\
49.5 \\
43.4\end{array}$ \\
\hline 70 & $\begin{array}{c}60 \\
90 \\
120 \\
\end{array}$ & $\begin{array}{l}53.7 \\
52.8 \\
48.9 \\
\end{array}$ & $\begin{array}{r}42.1 \\
41.4 \\
38.4 \\
\end{array}$ \\
\hline Temperature $\left({ }^{\circ} \mathrm{C}\right)$ & $\mathbf{T}_{1 / 2}(\mathbf{m i n}) *$ & Kr $\min ^{-1 * *}$ & $\mathbf{T m} * * *\left({ }^{\circ} \mathrm{C}\right)$ \\
\hline $\begin{array}{l}25 \\
37 \\
45 \\
55 \\
70 \\
\end{array}$ & $\begin{array}{c}196.96 \\
230.78 \\
129.41 \\
109.79 \\
85.06\end{array}$ & $\begin{array}{l}0.162 \\
0.145 \\
0.305 \\
0.379 \\
0.499\end{array}$ & 61 \\
\hline \multicolumn{2}{|c|}{ Effect of pH on haemolysin activity } & \multicolumn{2}{|c|}{ Effect of ions on haemolysin activity } \\
\hline $\mathrm{pH}$ values & $\begin{array}{c}\text { Hemolytic activity } \\
(\mathrm{HU} / \mathrm{ml})\end{array}$ & Metal ion (mM) & $\begin{array}{c}\text { Hemolytic activity } \\
(\mathrm{HU} / \mathrm{ml})\end{array}$ \\
\hline 4 & $112.8 \pm 0.1$ & $\mathrm{Fe}^{3+}(5 \mathrm{mM})$ & $126.1 \pm 0.2$ \\
\hline 5 & $114.5 \pm 0.4$ & $\mathrm{Cu}^{2+}(5 \mathrm{~mm})$ & $120.7 \pm 0.7$ \\
\hline 6 & $116.8 \pm 0.1$ & $\mathrm{Ca}^{2+}(5 \mathrm{~mm})$ & $135.1 \pm 0.2$ \\
\hline 7 & $126.7 \pm 0.2$ & $\mathrm{Mg}^{2+}(5 \mathrm{mM})$ & $82.5 \pm 0.6$ \\
\hline 8 & $115.6 \pm 0.4$ & $\mathrm{Zn}^{2+}(5 \mathrm{mM})$ & $74.0 \pm 0.3$ \\
\hline 9 & $100.3 \pm 0.7$ & $\begin{array}{l}\text { Iodine }(5 \mathrm{mM}) \\
\text { EDTA }(5 \mathrm{mM}) \\
\text { EDTA }(1 \mathrm{mM})\end{array}$ & $\begin{array}{c}59.9 \pm 1.0 \\
61.3 \pm 0.3 \\
104.8 \pm 0.8\end{array}$ \\
\hline
\end{tabular}

Table 4: In vivo toxicity of the fresh and heated haemolysin in mice

\begin{tabular}{|c|c|c|c|c|c|c|c|c|c|c|c|c|}
\hline \multirow{2}{*}{$\begin{array}{l}\text { Injected } \\
\text { material }\end{array}$} & \multirow{2}{*}{$\begin{array}{l}\text { Hemolytic titre } \\
(\mathrm{HU} / \mathrm{ml})\end{array}$} & \multirow[t]{2}{*}{ Dose $(\mathrm{ml})$} & \multicolumn{10}{|c|}{ Mortality of mice after days } \\
\hline & & & 1 & $\%$ & 2 & $\%$ & 3 & $\%$ & 4 & $\%$ & 5 & $\%$ \\
\hline Fresh & & 0.5 & $0 / 4$ & 0 & $1 / 4$ & 25 & $2 / 4$ & 50 & $3 / 4$ & 75 & $4 / 4$ & 100 \\
\hline \multirow{2}{*}{ (Toxin) } & 128 & 0.3 & $0 / 4$ & 0 & $0 / 4$ & 0 & $0 / 4$ & 0 & $0 / 4$ & 0 & $3 / 4$ & 75 \\
\hline & & 0.1 & $0 / 4$ & 0 & $0 / 4$ & 0 & $0 / 4$ & 0 & $0 / 4$ & 0 & $2 / 4$ & 50 \\
\hline Heated & & 0.5 & $0 / 4$ & 0 & $0 / 4$ & 0 & $0 / 4$ & 0 & $0 / 4$ & 0 & $2 / 4$ & 50 \\
\hline \multirow[t]{2}{*}{ (Toxoid) } & 64 & 0.3 & $0 / 4$ & 0 & $0 / 4$ & 0 & $0 / 4$ & 0 & $0 / 4$ & 0 & $1 / 4$ & 25 \\
\hline & & 0.1 & $0 / 4$ & 0 & $0 / 4$ & 0 & $0 / 4$ & 0 & $0 / 4$ & 0 & $0 / 4$ & 0 \\
\hline
\end{tabular}

$\mathrm{HU}=$ haemolytic units

Biochemical properties of purified haemolysin As shown in Table 3, maximum activity of the haemolysin was at $25^{\circ} \mathrm{C}$ for 30 minutes and decline of activity with increased exposure time. Also increasing temperature decreased enzymatic activity. With regards to the thermal kinetic parameters of the haemolysin, the half-life $\left(T_{1 / 2}\right)$ was longest $(230.78 \mathrm{~min})$ at $37^{\circ} \mathrm{C}$ and half-life temperature $(\mathrm{Tm})$ was estimated to be $61^{\circ} \mathrm{C}$. The haemolysin was approximately stable within $\mathrm{pH}$ range of 4-9 and maximum activity was at $\mathrm{pH}$ 7.0. The activity of the haemolysin was increased by the divalent ions $\mathrm{Ca}^{2+}$ followed by $\mathrm{Fe}^{+}, \mathrm{Cu}^{2+}$ and $1 \mathrm{mM}$ EDTA in that order. The haemolysin was inhibited in the presence iodine followed by $5 \mathrm{mM}$ EDTA, $\mathrm{Mg}^{2+}$ and $\mathrm{Zn}^{2}$ in that order.

\section{Mice toxicity of fresh and heated haemolysin}

As shown in Table 4, intraperitoneal (IP) injection of $0.5,0.3$ and $0.1 \mathrm{ml}$ of fresh toxin $(128 \mathrm{HU} / \mathrm{ml})$ caused mortality rate of $100 \%, 75 \%$, and $50 \%$ respectively in the injected mice. The haemolysin lost its toxicity after heating for 15 minutes in boiling water. The unprotected mice survived intraperitoneal (IP) injection of $0.1 \mathrm{ml}$ heated haemolysin. The haemolysin partially lost its toxicity at a dose of 0.5 and $0.3 \mathrm{ml}$, causing mortality rate of $50 \%$ and $25 \%$ respectively in the mice. With respect to the invitro toxinantitoxin neutralization test shown in Table 5 , three samples $(1,2,3)$ showed no haemolysis with different endpoints while the last 2 samples $(4,5)$ showed haemolysis. 
Table 5: In vitro toxin-anti-toxin neutralization test

\begin{tabular}{ccc}
\hline Sample & Haemolysis & Endpoint \\
\hline 1 & $-v e$ & $35 \mu \mathrm{l}$ \\
2 & $-v e$ & $40 \mu \mathrm{l}$ \\
3 & $-v e$ & $35 \mu \mathrm{l}$ \\
4 & +- e & -- \\
5 & + -ve & -- \\
\hline
\end{tabular}

\section{Discussion :}

Infection by multidrug resistant $P$. aeruginosa is a big challenge in patients with burn wounds with tendency to development of septicaemia and high risk of death. The organism is naturally resistant to a significant number of antimicrobials, and infections caused by it is therefore associated with high mortality rate because treatment is difficult due to reduced availability of effective antimicrobials (20). Research into novel therapies aside conventional antimicrobials is recommended to combat these multi-drug and sometimes pan-drug resistant organisms (21).

The anti-virulence approach is one of the new strategies to disarm $P$. aeruginosa infective arsenals by inhibiting the expression and activity of its virulence factors. This has the tendency to reduce its invasiveness and avoid emergence of resistance since proliferation is not affected (22). Haemolysin is one of the virulence factors of many organisms. $P$. aeruginosa produces haemolysin to sense and sequester iron from its environment, which also helps in survival of the pathogen by inhibiting host factors (23). Alpha-haemolysin of uropathogenic Escherichia coli can induce apoptosis of target host cells including neutrophils, T-lymphocytes and renal cells, which promotes exfoliation of epithelial cells of the bladder, contributing to nephropathogenicity (24).

Cultures of $P$. aeruginosa considered to be of proven virulence have been reported to have higher titers of extracellular haemolysin than cultures of less virulence ones. Intra-corneal injection of purified haemolysin produced extensive corneal opacification with extensive leukocytic infiltration of the tissue (25), and it was suggested that $P$. aeruginosa haemolysin played a role in the pathogenesis by effecting lysis of host cells and/or subcellular organelles, leading to the release of enzymes destructive to corneal tissue (25). Therefore targeting the haemolysin of $P$. aeruginosa can be a new non-antibiotic approach in the therapy of MDR strains of this organism in burn patients.

In this study, we purified, and chemically and immunologically characterized haemolysin of MDR $P$. aeruginosa PAO1 as a preliminary step to producing a vaccine for combating the effect of this virulence factor in burn patients. The haemolysin was more purified following chromatography with a factor of 29.7 fold. The purification profile using sephadex-G100 shows a sharp peak containing the active haemolysin in fractions 9 to 11 with specific activity $196.9 \mathrm{U} \mathrm{mg}^{-1}$ proteins compared to $6.6 \mathrm{U} \mathrm{mg}^{-1}$ of the crude protein. Our result agrees with another study on $P$. florescens (26) which reported that high performance liquid chromatography (HPLC) gives 32.6 fold increases in haemolysin purification. HPLC increased the purity of haemolysin of Bacillus mycoides by 40.8 folds with the assumption that filtration step is the key to the homogeneity observed. HPLC increases the purity of haemolysin because it polymerizes with other impurities (27).

Our study showed that using SDSPAGE, purified haemolysin of $P$. aeruginosa had one major band with molecular weight of approximately $37 \mathrm{kDa}$. Amino acid analysis of the haemolysin also showed that it is a hetero polymer. One study estimated the molecular weight of haemolysin produced by $P$. aeruginosa to be $78 \mathrm{kDa}$ using both SDSPAGE and Sephacryal S-200 column chromatography while another one estimated it to be $76 \mathrm{kDa}$ with high-performance size exclusion chromatography (28). The molecular weight of haemolysins of other organisms reported includes $12 \mathrm{kDa}$ for Actinobacillus actinomycetemcomitans (29) and $45 \mathrm{kDa}$ for Porphyromonas gingivalis (30). Similarly, extracellular protein showing haemolysin with SDS-PAGE profile of approximately $50 \mathrm{kDa}$ was characterized from a pathogenic Aeromonas hydrophila strain An4 isolated from marine catfish (31).

The amino acid composition of the haemolysin makes it a good immunogen (33), which can induce antibody formation. We investigated whether this haemolysin can be converted to toxoid by heating it for 15 minutes in boiling water to prepare the toxoid (17). The lack of haemolysis in some tubes in the in vitro toxin-antitoxin neutralization test can be attributed to presence of antitoxin in the serum obtained from a previously immunized (injected with heated 
toxin) mice. This serum is believed to contain antitoxin which neutralized the haemolysin. The samples that showed haemolysis may be due to the fact that the titer of the antitoxin was too low to neutralize the toxin (haemolysin). Other toxins of $P$. aeruginosa have been found to be immunogenic and mounted protective immune response in mice. Passive immunization of mice with antitoxin A gamma globulin protected mice against the lethality of intraperitoneal infection with $P$. aeruginosa (34). Pavlovskis et al., (35) and Snell et al., (36) observed that passive immunization of mice with specific antitoxin increased the survival of burned mice infected with toxigenic strains (but not with non-toxigenic strains) compared to control mice. Combining antibiotic therapy (gentamicin) with passive antitoxin therapy significantly improved the survival of the burned infected mice compared to infected mice receiving only antitoxin (37).

\section{Conclusion:}

This study concluded that haemolysin of $P$. aeruginosa PAO1 is a protein of $37 \mathrm{kDa}$ with $27.7 \%$ glycine content. The crude haemolysin has a haemolytic activity of $32 \mathrm{HU} / \mathrm{ml}$ and $128 \mathrm{HU} / \mathrm{ml}$ after purification with gel filtration on Sephadex G-100, with maximum activity at $25^{\circ} \mathrm{C}$ for 30 minutes at $\mathrm{pH} 7$ with half life temperature $\left(\mathrm{T}_{1 / 2}\right)$ of $61^{\circ} \mathrm{C}$. The haemolysin activity is enhanced by $\mathrm{Ca}^{2+}$ and $\mathrm{Fe}^{3+}$ and inhibited by iodine and $5 \mathrm{mM}$ EDTA. The haemolysin lost its activity by heating for 15 minutes in boiling water and induces neutralizing antibodies in vaccinated mice. It is recommended that haemolysin of $P$. aeruginosa $\mathrm{PAO} 1$ be investigated further as a potential component of vaccine for prevention of haemolysis caused by multidrug resistant strains of $P$. aeruginosa in burn patients.

\section{Conflict of interest:}

No conflicts of interest is declared

\section{Authors' contributions:}

AAA and WEH were responsible for concept and design of the study. All authors contributed to data collection. AME and EHAH undertook acquisition and interpretation of data and drafting of the manuscript. AAA undertook critical review of the manuscript. All authors agreed to the final draft.

\section{References:}

1. Cochran, A., Morris, S.E., Edelman, L.S., et al. Systemic Candida infection in burn patients. Surg Infect (Larchmt). 2002; 3 (4): 367-374.
2. Biswal, I., Arora, B. S., Kasana, D., et al. Incidence of multidrug resistant Pseudomonas aeruginosa isolated from burn patients and environment of teaching institution. J Clin Diagn Res. 2014; 8 (5): DC 26-29.

3. Gillespie, S. H., and Bamford, K. B. Medical Microbiology and Infection at a Glance. 4th edition, Wiley-Blackwell; 2012.

4. Kolmos, H. J., Thuesen, B., Nielsen, S., et al. Outbreak of infection in a burns unit due to Pseudomonas aeruginosa originating from contaminated tubing used for irrigation of patients. J Hosp Infect. 1993; 24: 11-21. Bownik, A., and Siwicki, A. Effects of staphylo coccal haemolysins on the immune system of vertebrates. Centr Eur J Immunol. 2008; 33 (2): 87-90.

6. Schaber, J. A., Carty, N. L., MacDonald, N.A., et al. Analysis of quorum sensing-deficient isolates of Pseudomonas aeruginosa. J Med Microbiol. 2004; 53: 841-853.

7. Attila, C., Ueda, A., Cirillo, S. L., et al. Pseudo monas aeruginosa PAO1 virulence factors and poplar tree response in the rhizosphere. Microb Biotechnol. 2007; 1(1): 17-29.

8. Cheesbrough, M. District Laboratory Practice in Tropical Countries Part-2. Cambridge University Press, Cambridge, New York, Melbourne, Madrid, Cape Town, Singapore, São Paulo.2006. Clinical and Laboratory Standards Institute (CLSI). Performance standards for antimicrobial disk susceptibility tests; $26^{\text {th }}$ approved standards. Document M1002-S. Wayne, PA: CLSI; 2016.

10. Beecher, D. J., and Wong, A. C. Identification of haemolysin BL-producing Bacillus cereus isolated by a discontinuous hemolytic pattern in blood agar. Environ Microbiol. 1994; 60 (5): 1646-1651.

11. Lowry, O. H., Rosebrough, N. J., Farr, A. L., et al. Protein measurements with the Folin phenol reagent. J Biol Chem., 1951; 193: 265-275.

12. Berk, R. S. Production and characterization of Pseudomonas aeruginosa hemolysin. J Bacteriol. $1962 ; 88$ (3):559-565.

13. Liu, P. V. Survey of haemolysin production among species of Pseudomonads. J Bacteriol. 1957; 74:718-727.

14. Laemmli, U. K. Cleavage of structural proteins during the assembly of the head of bacterio phage T4. Nature (London). 1970; 227: 680685.

15. Tous, G. I., Fausnaugh, J. L., Akinyosoye, O., et al. Amino acid analysis on polyvinylidene difluoride membranes. Anal Biochem. 1989; 179: 50-55.

16. Whitaker, J. R. Principles of enzymology for food sciences. In Enzyme inhibitors, New York: Marcel Dekker. 1972; 255-282.

17. Khalil, M. A. Studies on the control of some haemolytic bacteria. Ph.D. Thesis, Botany Department, Faculty of Science, Tanta University. 2009.

18. Abraham, E. Intranasal immunization with bacterial polysaccharide containing liposomes enhances antigen-specific pulmonary secretory antibody response. Vaccine. 1992; 10 (7): 461468.

19. Kotrla, T. Fall 2014 tentative schedule'. MLAB 1335 Immunology/Serology 2014. Available at <http://www.austincc.edu/mlt/ser/ser schedule.html/> Accessed at October 14, 2014.

20. Bhatt, P., Rathi, K. R., Hazra, S., et al. Pre valence of multidrug resistant Pseudomonas aeruginosa infection in burn patients at a tertiary care centre. IJB. 2015; 23 (1): 56-59.

21. Kaur, I. Novel Strategies to Combat Antimicrobial Resistance. J Infect Dis Ther. 2016; 4: 292.

22. Galdino, A. C. M., de Oliveira, M. P., Ramalho, T. C., et al. Anti-Virulence Strategy against the 
Multidrug-Resistant Bacterial Pathogen Pseudomonas aeruginosa: Pseudolysin (Elastase B) as a Potential Druggable Target. Curr Protein Pept Sci. 2019; 20 (5): 471-487

23. Gupta, P., Gupta, R. K., and Harjai, K. Multiple virulence factors regulated by quorum sensing may help in establishment and colonization of urinary tract by Pseudomonas aeruginosa during experimental urinary tract infection, Indian J Med Microbiol. 2016; 31(1): 29-33.

24. Parvez, S. A., and Rahman, D. Virulence Factors of Uropathogenic E. coli. In Behzadi P. (ed). Microbiology of Urinary Tract InfectionsMicrobial Agents and Predisposing Factors, 2018. DOI: 10.5772/intechopen.79557

25. Johnson, M. K., and Allen, J. H. The role of hemolysin in corneal infections with Pseudomonas aeruginosa. Invest Ophthalmol Vis Sci. 1979; 17 (5): 480-483.

26. Crevel, C., Sally U., Carne, A., et al. Purification and properties of Zinc Metallophospholipase C from Pseudomonas fluorescens. Eur J Biochem. 1994; 224 (3): 845-852.

27. Wang, C. G., Chen, M. K., and Chen, T. Improved purification and some properties of a novel phospholipase $\mathrm{C}$ from Bacillus mycoides strains 970. Afr J Microbiol Res. 2010; 4 (7): 523-526.

28. Berka, R. M., and Vasil, M. L. Phospholipase C (heat-labile hemolysin) of Pseudomonas aeruginosa: purification and preliminary characterization. J Bacteriol. 2002; 152 (1): 239245.

29. Kimizuka, R., Miura, T., and Okuda, K. Characterization of Actinobacillus actinomycetemco mitans hemolysin. Microbiol Immunol. 1996; 40: 717-723.
30. Deshpande, R.G., and Khan, M.B. Purification and characterization of hemolysin from Porphy romonas gingivalis A7436. FEMS Microbiol Lett. 1999; 176:387-394.

31. Pandey, A, Milind, N. M., and Dubey, S. K. Hemolysin, Protease, and EPS Producing Pathogenic Aeromonas hydrophila Strain An4 Shows Antibacterial Activity against Marine Bacterial Fish Pathogens. J Marine Biol. 2010; Article ID 563205 http://dx.doi.org/10.1155/2010/563205

32. Russo, T. A., Davidson, B. A., Genagon, S. A., et al. $E$. coli virulence factor haemolysin induces neutrophil apoptosis and necrosis/lysis in vitro and necrosis/lysis and lung injury in a rat pneumonia model. Am J Physiol Lung Cell Mol Physiol. 2005; 289 (2): L207-L216

33. Doan, T., Melvold, R., Viselli, S., et al. Lippincott Illustrated Reviews: Immunology. 2nd edition. Harvey RA editor. Wolters Kluwer, Lippincott Williams \&Wilkins.

34. Liu, P. V., and Hsieh, H. Exotoxins of Pseudomonas aeruginosa III. Characteristics of antitoxin A. J Infect Dis 1973; 128: 520-526.

35. Pavlovskis, O.R., Pollack, M., Callahan, L.T., et al. Passive protection by antitoxin in experimental Pseudomonas aeruginosa burn infections. Infect Immun. 1977; 18: 596-602

36. Snell, K., Holder, I. A., Leppla, S. A., et al. Role of exotoxin and protease as possible virulence factors in experimental infections with Pseudomonas aeruginosa. Infect Immun. 1978; 19: 839-845

37. Woods, D. E., and Iglewski, B. H. Toxins of Pseudomonas aeruginosa: New Perspectives. Rev Infect Dis. 1983;5 Suppl 4:S715-22. 